\title{
The Potential of Renewable Energy in Timor-Leste: An Assessment for Biomass
}

\author{
Lelis Gonzaga Fraga ${ }^{1,2, *} \mathbb{C}$, José Carlos F. Teixeira ${ }^{1}$ and Manuel Eduardo C. Ferreira ${ }^{1}$ \\ 1 Department of Mechanical Engineering, University of Minho, 4800-058 Guimarães, Portugal; \\ jt@dem.uminho.pt (J.C.F.T.); ef@dem.uminho.pt (M.E.C.F.) \\ 2 Department of Mechanical Engineering, Universidade Nacional Timor Lorosa'e, Rua Formosa, 10, Dili, \\ Timor-Leste \\ * Correspondence: lelisfraga@hotmail.com; Tel.: +351-926946326
}

Received: 2 February 2019; Accepted: 10 April 2019; Published: 15 April 2019

check for updates

\begin{abstract}
This paper assesses the potential of biomass energy resources in Timor-Leste (TL). Although other renewable energy sources are mentioned in this article, such as wind energy, solar energy, hydropower, bioenergy, including bioethanol and biogas, the main goal is to gather the data on biomass in TL and provide such data as useful information for a wide range of end-users. The current evaluation is based on various sources which include previous assessments on biomass and other renewable sources. The energy potential of biomass in TL apart that resulting from vegetation or flora and animals is also derived from agricultural waste, such as waste from rice, corn, and coffee. The analyses also include the contribution of agricultural waste, animal waste, and that from urban waste. The results from this article show that the potential of usable biomass energy in TL from forestry and agriculture is $1.68 \times 10^{6}$ toe/year, animal waste is $4.81 \times 10^{3}$ toe/year, and urban solid waste amounts to $9.55 \times 10^{3}$ toe/year. In addition, it is concluded that biomass alone can fully replace fossil fuels for electricity generation.
\end{abstract}

Keywords: renewable energy; biomass; waste

\section{Introduction}

Renewable energy is an important resource, which is widely available in nature. As fossil fuels are becoming scarce and are associated with climate change [1], a great opportunity is presented for the development and utilization of renewable energy [2]. Both government institutions and private sectors are starting investing in renewable energy development, and many developing and emerging countries start working and investing in renewables and related infrastructure. It was estimated that globally, renewable energy accounted for apparently $18.2 \%$ of the total final energy consumption in 2016 [3]. The International Energy Agency reported that in 2016, the worldwide total primary energy supply (TPES) was 13,761 Mtoe, of which 13.7\%, or 1882 Mtoe (up from 1819 Mtoe in 2015), was produced from renewable sources [4]. The amount of global renewable energy supply, including solid biofuels/charcoal $62.4 \%$, hydropower (2.5\% of world TPES and $18.6 \%$ of renewables), and the rest, is speed over other sources, such as liquid biofuels, wind, geothermal, solar, biogases, renewable municipal waste, and tide. Depending on the sources and methods, other databases may estimate varying figures and indexes for renewable energy; nonetheless, the scenarios are in agreement with the previous statement. In the overall framework for the sustainable development goals, reported by the International Council for Science and International Social Science Council, amongst the 16 are included: end poverty, ensure healthy lives, ensure equitable quality education, ensure modern energy for all, reduce inequality, etc. These goals are targeted to be achieved in the year of 2030, named as 2030 Agenda. In this Agenda, Goal number seven aims to ensure universal access to affordable, reliable, 
sustainable, and modern energy for all. This is articulated with the goal of increasing the share of substantially renewable energy in the global energy mix by 2030 [5]. From this overview of renewable energy development, the policymaker has a key role in defining the process and routes to achieve the defined targets $[3,4,6]$.

Biomass is one of the renewable energy sources, which contributes to the sustainable development of energy supply, with future development of bioenergy depending on the available biomass resources and their development [7]. The advantages of biomass, besides being a renewable and inexhaustible fuel source [1], is that it provides employment opportunities in rural areas [8]. Global utilization of biomass is increasing because being considered carbon neutral [9] can address the pressing need to reduce greenhouse gas emissions [10]. Biomass can be obtained from agricultural waste or fast-growing plants [11], industrial residues and process waste, sewage, and animal wastes [12]. Biomass is considered as an accessible and affordable source of energy, especially in rural areas [1]. However, the use of bioenergy for fuel applied in transportation and power sectors may have an impact on food availability and cost. This is a fact that the use of land for bioenergy production competes with alternative outputs from land and can affect agricultural land. The solution for this issue is that biofuel feedstocks must come from land that was neither forested before nor necessary for food crops (set aside land) as adopted by the U.S. Renewable Fuel Standard [13].

Timor-Leste (TL), a tropical country located on the south-east side of the Indonesia archipelago, is approximately 500 miles north of Australia, being washed by the Banda Sea and the Timor Sea to the north and south, respectively [14]. The country's size is $15,410 \mathrm{~km}^{2}$, including the Oecusse enclave in the western part of the island and the islands of Atauro in the north and Jacob to the east. The territory of TL extends for about $265 \mathrm{~km}$ long (East-West) and $90 \mathrm{~km}$ wide (North-South) and reaches close to $3000 \mathrm{~m}$ in altitude. Administratively TL is divided into 13 districts, and the population of TL was about 1,183,643 inhabitants in 2015 [15]. Although statistical data is recent and unreliable, the total primary energy consumption has not varied substantially over the last years and was approximately 152 ktoe (as of 2014). The $\mathrm{CO}_{2}$ emissions (resulting exclusively from petroleum products) were 0.36 ton/capita in 2014. This figure is less than an order of magnitude than that in developed countries, such as Western Europe. Nonetheless, this represents a three-fold increase over a decade.

Although TL is a net exporter of crude oil, there are no distilling facilities in the territory. Currently, the energy consumption in TL relies on the use of imported energy, mostly for electricity generation and transportation fuels, which leads to high expenses for the annual energy budget. As an example, in 2007, the government of TL spent approximately US \$26 million per year on gasoline, which increased in subsequent years [16].

As a tropical country, TL has the potential for a wide variety of renewable energies, such as solar, wind, hydro, and bioenergy. Such resources of renewable energy, if properly managed, could make a useful contribution to the energy supply and consumption in TL in the future.

Wood biomass is mostly used for heating and cooking purposes in a household. Overall, it is estimated that up to $90 \%$ of the energy needs of TL citizens are provided by biomass as the electricity consumption is very low. In fact, the annual electricity consumption per capita is $97 \mathrm{kWh}$, well below the average in Europe ( $5500 \mathrm{kWh})$. Because of the growing interest in biomass as an energy source, many nations have dedicated a great effort into assessing correctly their potential, in order to support the development of policies to promote their use and increase their share of the energy unit. Due to multiple reasons, there is not a comprehensive assessment as such for TL. Although a brief overview of the renewable energy is presented here, the main objective of this paper is to collect the data and information regarding the potential of biomass resource in TL. The amount of biomass, including forestry and agriculture, animal, and urban waste, is calculated in terms of useful energy. It is a mostly scattered information regarding biomass resources, and this paper aims to organize such information into a coherent and structured body that can be useful for future use and to draw the likely impact that endogenous renewable energy resources can have in a small country that is taking its first steps into sustainable development. 


\section{Research Methods}

As mentioned, this paper assesses the potential of renewable energy resources, mostly biomass, in TL. The data included the contribution from forestry, agriculture, urban, and animal waste and was collected by various methods at different times. This section details the various methods deployed.

\subsection{Biomass Estimation from Forestry}

The methodology applied to estimate the recoverable biomass resources follows various steps [14]: the land was organized in different categories, and for each one, the respective area was quantified; the expected average productivity was assumed; it was defined the period of rotation of species. The estimation of annual increment of biomass above ground was done by applying a simple calculation regarding the annual increment $(I$, ton/ha/year), average productivity $(P$, ton/ha), and age of rotation ( $R$, years), with $I=2 P / R$. The usable biomass was estimated by taking into account its accessibility and the dynamics of the ecosystem. Meanwhile, the Shuttle Radar Mission Topography of National Aeronautics and Space Administration (NASA) was used to identify the different elevations of the land.

\subsection{Biomass Estimation from Agricultural}

The methodology used to estimate the biomass resources from agriculture included [14]: quantification of the annual production of the most representative large scale crops production and their waste for energy utilization in each district; selection of the empirical values for the ratio of production/waste produced, whether resulting in the field or from the crop processing. This data enables to mapping the availability of energy production from agriculture.

\subsection{Biomass Collection from Urban Waste}

The urban solid waste from Dili city was calculated based on the mean waste carried by trucks $\left(\mathrm{m}^{3}\right)$ multiplied by the number of trucks per day [17].

\subsection{Biomass Collection from Animal Waste}

Regarding the biomass from animal waste, this data is based upon the number of animals, organized by the most relevant species, which were registered in 2009. From this data, the waste was

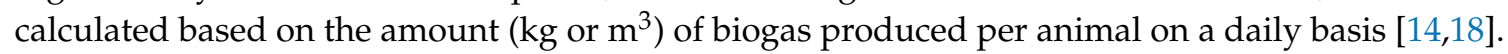

\section{Assessment of Renewable Energy Resources}

\subsection{Renewable Energy Resources in Timor-Leste}

The renewable energy resources in TL, including wind, solar, hydro, and bioenergy, are briefly presented here as they may play an important role in the future energy mix.

In tropical and mountain areas, the potential of wind varies with time as it depends on winds driven by the thermal gradients and the local geographical conditions. In TL, information regarding the potential of wind power has been identified by a preliminary survey, suggesting that TL has several areas suitable for deployment of wind turbines [19]. The State Secretariat for Energy Policy (SEPE) during the term 2007-2012 expected an electricity production with a capacity of 11 MW in the area of Lariguto/Osso (Viqueque district) and Laleia (Manatuto district), combined with a capacity of 2 and $4 \mathrm{~kW}$ in the area of Turiscai/Foholau (Manufahi district) and Ataúro/Makadede (Dili district) [20].

$\mathrm{TL}$, as a tropical country, has a huge potential for direct solar energy harvesting. A previous survey shows that the entire territory of TL has the potential to successfully produce solar energy. In terms of average annual range, it varies between 14.85 and $22.33 \mathrm{MJ} / \mathrm{m}^{2}$ per day, which indicates that the whole territory of TL has the potential to successfully generate solar energy [19]. This compares favorably with Australia that has the highest average solar radiation per square meter of any continent in the world and whose potential annual average of solar radiation varies between 18 and $24 \mathrm{MJ} / \mathrm{m}^{2}$ 
per day in the northwest and center of the country, the most favorable regions [21]. Due to the solar energy available in the country, a total amount of 1228 units of solar energy have been installed for family households in remote areas [20].

TL has a potential for developing the mini hydropower in specific districts. The analysis from the Strategic Development Plan (PED, in Portuguese) identified nearly forty locations that could generate power in the range from 1.2 MW to $50 \mathrm{MW}$ [19]. The survey conducted by SEPE in the previous government describes that mini hydropower with the capacity of $36.1 \mathrm{GWh} /$ year and $8.8 \mathrm{GWh} /$ year have been installed in Atsabe (Ermera district) and Bulobo (Bobonaro district), respectively. Besides, a center for mini-hydro with a capacity of $10 \mathrm{~kW}$ capable of supplying 166 households, will still be identifying [20]. In addition, in the district of Lautem (Ira-lalaru), the potential of hydropower can be produced with the capacity of 12-28 MW [16], and also one mini hydroelectric power plant with the maximum capacity of $326 \mathrm{~kW}$ is located in Gariuai (Baucau district) [22].

\subsection{Biomass Potential in Timor-Leste}

Bioenergy is the general term regarding the energy derived from carbon-based materials, such as wood, straw or animal waste, where the living matter is relatively recent as opposed to fossil fuels. Such materials can be burned directly to produce heat or power, but can also be converted into biofuels. These (as charcoal and biodiesel) are mostly made from wood and plant seeds [14].

TL has a large potential of biomass as an energy resource. The analysis described in the PED [19] shows that the amount of biomass above the ground in TL is linked with the highest concentration of biomass plants in the tropical forests in upland areas, medium altitude areas, and lowland forest. Because of the terrain, the degree of accessibility of such resources varies significantly, and those from mountain areas are of difficult access.

Various types of biomass from agriculture available in TL, such as from forestry, include tree trunks, branches, leaves, shoots, bark, pine cones, etc. Other biomass sources are from agriculture plantations, such as coffee, rice fields, agricultural parcels with surrounding trees, meadows, etc. [14].

The economic structure of TL is mostly dependent upon the agriculture productivity. The 2001 Census identifies that the agricultural sector is the main activity for about $73 \%$ of the population and contributes to $25.4 \%$ to the total value of the GDP of TL [14]. This pattern is still valid today. For a large portion of the population, several agriculture plantations are their main livelihood, such as cassava, beans, sweet potatoes, and soybeans, while the most significant crops for life sustain are rice, corn, and coffee, which is the main commercial production. The biomass resources from agriculture waste can be obtained from those productivities. Other vegetable wastes that can contribute to power production include provenance tree, shrub, and herbaceous as a part of the forest and agricultural product. Table 1 summarizes the most important sources of biomass for energy purposes. The data include the total existing biomass for the various categories and the corresponding annual yield. The usable annual yield takes into account how easily the source can be accessed.

Being a mountainous island, some $30 \%$ of the amount of biomass actually produced in TL occurs at altitude (mostly varying between 1000 and $2000 \mathrm{~m}$ ). Previously published data show that $73 \%$ of the East Timorese territory is categorized as forestry land, being some of that area as Tropical Monsoon Forest, such as the district of Lautem [14]. In such regions (tropical forest in the highlands and also at the middle and lower altitudes, provided it is dense forest), the annual yield varies between 90 and 160 tons/ha. Overall, the data show that the total stock of biomass in ecosystems suitable for the production of the electricity, including forestry, agriculture, and degraded pastures and forests, is $127,528,335$ tons, with an annual increase of 5,222,999 tons/year (4\%), much of which is usable $(4,911,051$ tons/year) [14]. Many species are endogenous to TL. One may take some for comparison purposes with other nations. Taking eucalyptus, in TL, the percentage of biomass in the ecosystem, based on the land occupation, is $15.99 \%$ [14]. While the percentage of biomass in the ecosystem in another country, such as Portugal, was $8.8 \%$ in the year 2010 [23]. From the data in Table 1, one can also estimate the annual yield (productivity) of eucalyptus. Considering a total area of 246,403 ha 
dedicated to eucalyptus, the yield rate is 4.5 tons/year/ha. The productivity depends on many factors (soil, water, and climate) but varies between 2.4 and 15 tons/year/ha [24].

Table 1. Amount of the stock biomass in ecosystems for power production. Data reproduced with the permission from the publisher [14]. Notes: a.g. = above-ground; s.o. = soil occupation.

\begin{tabular}{|c|c|c|c|c|}
\hline $\begin{array}{c}\text { categorized by } \\
\text { Soil Occupation } \\
\text { (s.o.) }\end{array}$ & Class of s.o. & $\begin{array}{l}\text { Biomass a.g. } \\
\text { (ton) }\end{array}$ & $\begin{array}{c}\text { Annual yield of } \\
\text { Biomass a.g (ton/year) }\end{array}$ & $\begin{array}{l}\text { Usable Biomass } \\
\text { (ton/year) }\end{array}$ \\
\hline \multirow{11}{*}{ Forest } & Mangrove forest & 2893 & 386 & 0 \\
\hline & Coastal forest & $1,021,854$ & 68,209 & 68,209 \\
\hline & $\begin{array}{l}\text { Humidity tropical forest of } \\
\text { high zone, various species }\end{array}$ & $10,608,297$ & 265,207 & 79,562 \\
\hline & Casuarina & $6,192,806$ & 154,820 & 46,446 \\
\hline & Eucalyptus & $22,225,526$ & $1,111,276$ & $1,111,276$ \\
\hline & $\begin{array}{l}\text { Humidity tropical forest of } \\
\text { lower zone, various species }\end{array}$ & $20,319,775$ & 678,007 & 678,077 \\
\hline & Teak & 305,296 & 15,265 & 15,265 \\
\hline & $\begin{array}{l}\text { Dense humidity forest, of a } \\
\text { lower and medium zone }\end{array}$ & $40,985,126$ & $1,639,405$ & $1,639,405$ \\
\hline & $\begin{array}{l}\text { Sparse humidity forest, of a } \\
\text { lower and medium zone }\end{array}$ & $20,704,695$ & 828,647 & 828,647 \\
\hline & Mount forest & 940,339 & 18,765 & 1877 \\
\hline & Swamp & 10,903 & 725 & 0 \\
\hline \multirow{5}{*}{ Agriculture field } & $\begin{array}{l}\text { Agriculture land (not } \\
\text { irrigated) }\end{array}$ & $1,003,663$ & 134,491 & 134,491 \\
\hline & Coffee plantations & $2,221,419$ & 222,142 & 222,142 \\
\hline & $\begin{array}{l}\text { Agriculture production of a } \\
\text { coconut tree }\end{array}$ & 470,793 & 37,663 & 37,663 \\
\hline & Abandoned agricultural areas & 5147 & 690 & 690 \\
\hline & Irrigation areas & 200,000 & 26,800 & 26,800 \\
\hline \multirow{5}{*}{$\begin{array}{l}\text { Degraded pastures } \\
\text { and forests }\end{array}$} & Uncultivated & 1594 & 105 & 105 \\
\hline & Savannah & 82,091 & 5473 & 5473 \\
\hline & Pastures & 222,097 & 14,658 & 14,658 \\
\hline & Shrubs and herbaceous species & 4021 & 265 & 265 \\
\hline & Total & $127,528,335$ & $5,222,999$ & $4,911,051$ \\
\hline
\end{tabular}

In addition, the distribution through the territory of the amount of estimated biomass (stock) as the total existing biomass above-ground (a.g.), the annual growth and the usable biomass are depicted in Figure 1. The data show that the districts of Manatuto, Viqueque, Lautem, and Covalima are those with the largest resources. In addition, soil productivity does not vary significantly across the country, with an average yield spread of 3-4 tons/year per hectare. 


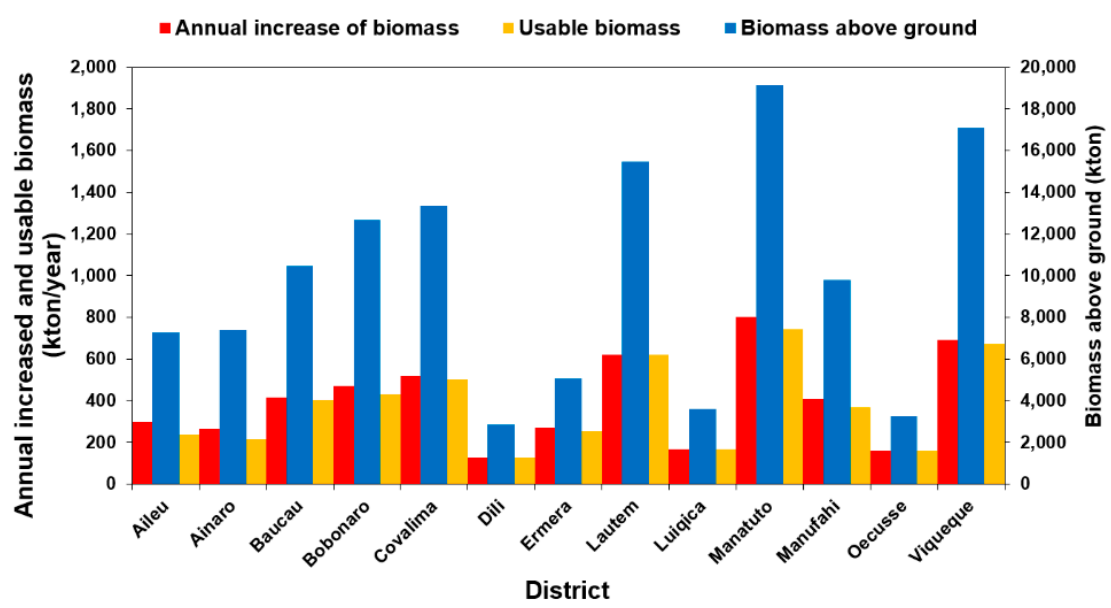

Figure 1. Estimation of the above-ground biomass stock at the district level. Based on data from [14]. Adapted with permission from the publisher.

\subsection{Waste Biomass}

Waste biomass in TL can be obtained from different sources, including animal waste, agriculture activities, forestry, and urban waste/solid waste (MSW).

\subsubsection{Waste Biomass from Agriculture}

The residues from agriculture crops, such as rice, corn, and coffee, are also available in the country. The total production of rice is 60,516 tons/year resulting in a waste production of 102,875 tons/year that includes straw and shell at 90,773 and 12,102 tons/year, respectively. From this, the usable waste from rice is 25,718 tons/year. The total productivity of corn is 65,202 tons/year, while the waste production is 84,760 tons/year with a usable waste of 21,190 tons/year. The total production of coffee is 9900 tons/year with a waste production of 9109 tons/year, and the usable waste is 2278 tons/year, as described in Figure 2 [14]. Taking the usable waste data, the waste biomass from corn in TL is approximately $95 \mathrm{GWh} /$ year [14] compared to Portugal which is $3378 \mathrm{GWh} /$ year [23].

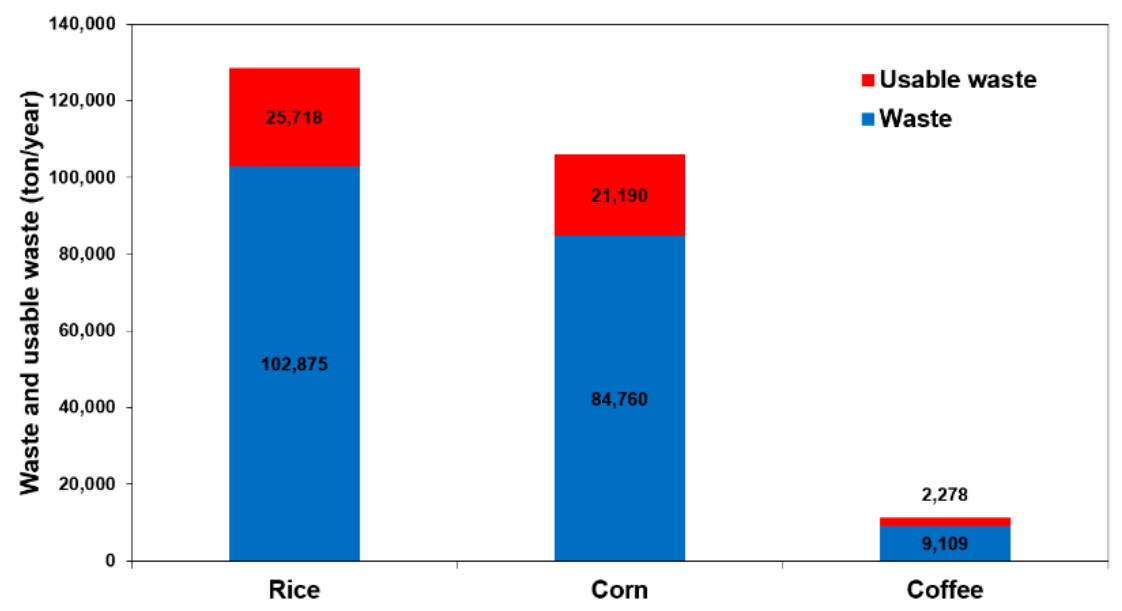

Figure 2. Waste from rice, corn, and coffee plantation. Based on data from [14]. Adapted with permission from the publisher.

The availability of the usable biomass mentioned above, which is composed of agricultural (rice, corn, and coffee), agroforestry, and animals, corresponds to 49,188, 4,901,483 and 60,636 tons/year, respectively. The districts with the highest potential of biomass energy and with usable waste biomass above 500 ktons/year are Manatuto, Viqueque, Lautem, and Covalima [14] (see Figure 3). 


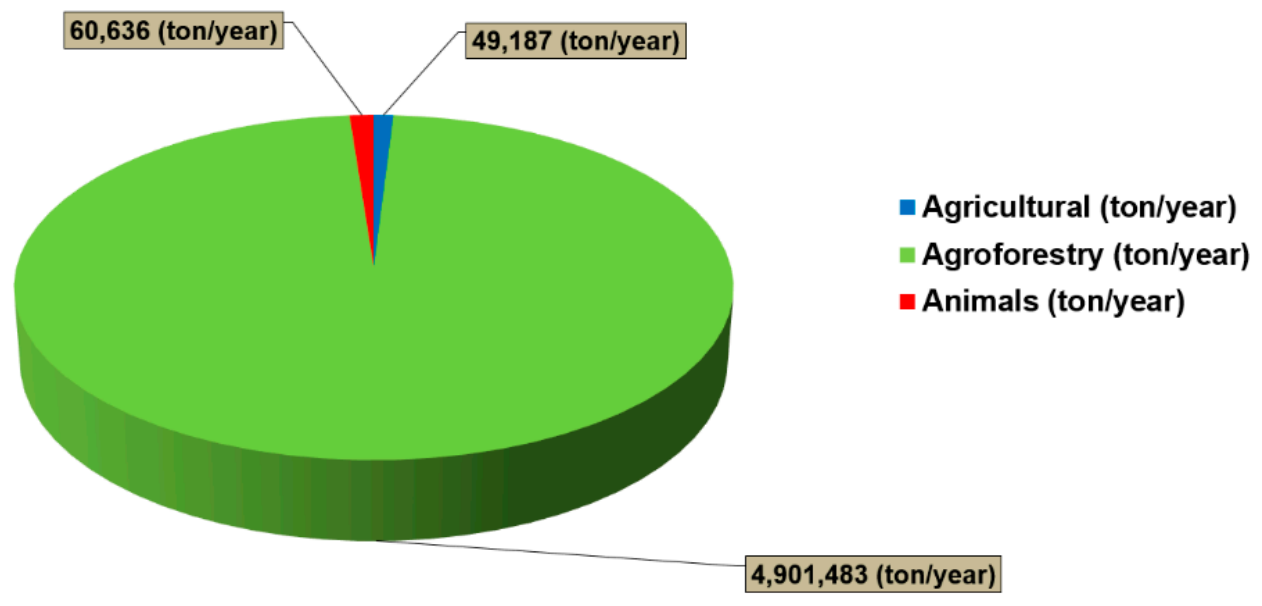

Figure 3. The availability of the usable biomass from agricultural, agroforestry, and animals in the country. Based on data from [14]. Adapted with permission from the publisher.

\subsubsection{Municipal Solid Waste}

TL has 13 districts; but from population Census of 2015, the three most populated districts are Dili $(277,279)$, Ermera $(125,702)$, and Baucau $(123,203)$ as referred by Ferreira et al. [15]. In this paper, the information on the municipal solid waste (MSW) concerning Dili is presented because being the capital city of the country and also a center for various activities, it produces the maximum waste. Data from 2007 show that the collection of MSW in Dili is about 60 tons every day [16]. The waste in Dili is produced from households, markets, offices, schools, hospitals, and at the bus station. Amongst those, households and markets contribute to the largest share of waste. All the waste is collected and disposed to the final site, located $26 \mathrm{~km}$ from Dili city. It shows that the volume of the waste collected is around 158 tons/day in 2012 [17], assuming that for an economic developing country the bulk density of MSW is $660 \mathrm{~kg} / \mathrm{m}^{3}$ [25]. The increase in the amount of MWS from 2007 to 2012 is an indication of the increase in activity and population growth. The population growth in Dili during the period 2004 to 2010 and 2010 to 2015 is $33.17 \%$ and $18.48 \%$, respectively, which is the largest among other districts $[15,26]$. Also, the stabilization of political life after the unrest following independence has contributed to such an evolution. The urban waste collection in Dili compared with another city, such as Kupang (East Nusa Tenggara, Indonesia), in the west of TL shows that in 2009 the waste collected was approximately 203 tons/day [27].

\subsubsection{Waste Generated by Animal Husbandry}

Based on a preliminary survey, it was estimated that the number of animals in the territory of TL in 2005 was 469,301 ruminants [14]. The animals mentioned in the survey include large species, such as buffalo, cow, and horse, mid-size animals, such as pig, goat, and sheep, and small livestock, such as chickens and ducks, with a total number of those animals estimated at 1,603,700 units (see Table 2). The waste products from those animals are approximately 505,317 tons/year, and the usable waste is 60,636 tons/year (see Table 3) [14].

Several districts, which include Viqueque, Oecusse, Baucau, and Bobonaro, have the potential of animal waste above 5000 tons/year, and from a total potential of approximately 60,000 tons/year, the districts of Viqueque and Baucau may contribute with $28 \%$ of the whole resource. The activities conducted by SEPE in the previous government resulted in the construction of two digesters with 20 and $10 \mathrm{~m}^{3}$, capable of supplying biogas for 300 families in the Manufahi district [20]. Based on the information in TL, domestic and industrial waste can be processed in the factories, especially, designed to produce electricity [19]. The waste generated from animal husbandry in TL from different species mentioned in Table 3 is approximately 56 GWh/year [14] compared to Portugal from three different species, such as chickens, swine, and bovine, which is $725.4 \mathrm{GWh} /$ year [23]. 
Table 2. Number of domestic animals in the country. Data reproduced with the permission from the publisher [14].

\begin{tabular}{ccccccc}
\hline District & Cow & Buffalo & Horse & Goat/Sheep & Pig & Poultry \\
\hline Aileu & 5635 & 1342 & 1505 & 2261 & 3734 & 16,557 \\
\hline Ainaro & 11,541 & 10,145 & 7985 & 4037 & 29,717 & 37,792 \\
\hline Baucau & 8422 & 21,690 & 9577 & 32,279 & 39,608 & 73,280 \\
\hline Bobonaro & 27,587 & 7142 & 3162 & 8396 & 31,404 & 85,149 \\
\hline Covalima & 17,217 & 7608 & 1494 & 1765 & 20,049 & 27,405 \\
\hline Dili & 6966 & 901 & 968 & 42,173 & 72,588 & 98,279 \\
\hline Ermera & 10,768 & 4703 & 3389 & 2647 & 19,102 & 34,011 \\
\hline Lospalos & 10,143 & 2682 & 1458 & 11,693 & 41,082 & 98,299 \\
\hline Luiqica & 8967 & 13,161 & 3437 & 5203 & 21,134 & 42,279 \\
\hline Manatuto & 8651 & 8588 & 2823 & 12,360 & 14,323 & 18,840 \\
\hline Manufahi & 8664 & 6026 & 3655 & 1805 & 16,979 & 28,783 \\
\hline Oecusse & 26,818 & 2037 & 1950 & 8652 & 26,698 & 129,101 \\
\hline Viqueque & 22,714 & 22,644 & 6676 & 5189 & 48,118 & 60,088 \\
\hline \multirow{2}{*}{ Total } & $\mathbf{1 7 4 , 0 9 3}$ & $\mathbf{1 0 8 , 6 6 9}$ & $\mathbf{4 8 , 0 7 9}$ & $\mathbf{1 3 8 , 4 6 0}$ & $\mathbf{3 8 4 , 5 3 6}$ & $\mathbf{7 4 9 , 8 6 3}$ \\
\cline { 2 - 7 } & & \multicolumn{1}{c}{$\mathbf{6 0 3 , 7 0 0}$} & & \\
\hline
\end{tabular}

Table 3. Animal waste production and usable waste in the country. Data reproduced with the permission from the publisher [14].

\begin{tabular}{ccccccccc}
\hline \multirow{2}{*}{ District } & \multicolumn{9}{c}{ Waste Production (ton/year) } & \multicolumn{3}{c}{ Usable Waste } \\
\cline { 2 - 9 } & Cow & Buffalo & Horse & Goat/Sheep & Pig & Poultry & (ton/year) & (\%) \\
\hline Aileu & 6086 & 1932 & 813 & 407 & 806 & 596 & 1273 & 2.1 \\
\hline Ainaro & 12,464 & 14,609 & 4312 & 727 & 6419 & 1360 & 4883 & 8.1 \\
\hline Baucau & 9096 & 31,234 & 5172 & 5810 & 8555 & 2638 & 7587 & 12.5 \\
\hline Bobonaro & 29,794 & 10,284 & 1707 & 1511 & 6654 & 3065 & 6347 & 10.5 \\
\hline Covalima & 18,594 & 10,956 & 807 & 318 & 4330 & 987 & 4436 & 7.3 \\
\hline Dili & 7523 & 1297 & 523 & 7591 & 15,679 & 3538 & 4133 & 6.8 \\
\hline Ermera & 11,629 & 6772 & 1830 & 477 & 4126 & 1224 & 3147 & 5.2 \\
\hline Lospalos & 10,954 & 3862 & 787 & 2105 & 8874 & 3539 & 3369 & 5.6 \\
\hline Luiqica & 9684 & 18,952 & 1856 & 937 & 4565 & 1522 & 4562 & 7.5 \\
\hline Manatuto & 9343 & 12,367 & 1525 & 2225 & 3094 & 678 & 3619 & 6.0 \\
\hline Manufahi & 9357 & 8677 & 1974 & 325 & 3667 & 1036 & 3042 & 5.0 \\
\hline Oecusse & $\mathbf{2 8 , 9 6 3}$ & $\mathbf{2 9 3 3}$ & 1053 & 1557 & 5767 & 4648 & 5104 & 8.4 \\
\hline Viqueque & 24,531 & 32,607 & 3605 & 934 & 10,394 & 2163 & 9134 & 15.1 \\
\hline \multirow{2}{*}{ Total } & $\mathbf{1 8 8 , 0 2 0}$ & $\mathbf{1 5 6 , 4 8 3}$ & $\mathbf{2 5 , 9 6 4}$ & $\mathbf{2 4 , 9 2 5}$ & $\mathbf{8 2 , 9 3 0}$ & $\mathbf{2 6 , 9 9 5}$ & $\mathbf{6 0 , 6 3 6}$ & - \\
\cline { 2 - 9 } & & & $\mathbf{5 0 5 , 3 1 7}$ & & & - & - \\
\hline
\end{tabular}

\section{Future Development of Biomass Energy in Timor-Leste}

Future development of renewable energy in TL is important as the energy demand is increasing, while the stock of energy in terms of fossil fuel is decreasing. In addition, the necessity for creating a good environment to foster the development of renewable resource is an important issue that needs to be considered. 


\subsection{The State's Policy on Biomass Energy}

At approximately 745,174 hectares, the forest area of TL represents approximately $50 \%$ of the total land area. Biomass energy is available in certain parts of the country that are state-owned. TL has a law regulating all the natural resources in the country. According to that law, the state will hopefully show an interest in the development of the natural resources in the country, including biomass energy. Recently, the Government of TL has signed new global partnership for supporting the nation in its efforts to be effective in combating and diminishing the obstacle to the sustainability of biomass resources and to develop the energy access to the rural areas [28]. The partnership will be on the Production of Biomass as Sustainable Bioenergy (PBESB), and this project will be focused on the reduction of annual wood consumption for the traditional cooking stove. The previous SEPE has carried out many programs regarding the use of alternative energies, including solar panels, jatropha biofuels, and biogas. In addition, the law on alternative energy has been developed by SEPE [29].

\subsection{International Role}

International support is also a key element in the development of natural resources in the country. The Millennium Development Goal of achieving that $55 \%$ of territory be covered by forest remains an ambitious objective [19]. The consumption of energy from renewable energy sources in TL still represents a very small amount. Nonetheless, it is expected that the energy produced by wind, solar, hydropower, and other renewable sources may contribute to the mitigation efforts of TL to climate change and help to fulfill the obligations under international conventions on climate change [19].

\subsection{Potential Consumers of Biomass}

Firewood is an essential fuel for cooking in TL. According to the Japan International Cooperation Agency (JICA), it is estimated that in 2002 approximately $93 \%$ of households used biomass (firewood) to meet their energy needs, particularly for cooking and heating, which represents the consumption pattern of 1.3 million $\mathrm{m}^{3}$ [14]. Such a large amount of users for firewood has an impact on the biomass resources in the country [28]. The very traditional method of cooking can result in severe air pollution (mostly airborne particles) and health problems. Although such route is of great relevance, there is a pressing issue and opportunity to develop and disseminate efficient energy devices for domestic use.

\subsection{The Possibility of Future Development for Renewable Energy}

For TL, as a new country, the development of every sector is important to enhance and improve its economy. Development of renewable energy is a key factor to support the country to secure the energy supply in a sustainable manner.

Nowadays, the government has extended the electricity grid to supply electric power to the entire country. There are two generating power stations to provide electric power for the whole of TL. One is at Hera (Dili district) with a capacity of $120 \mathrm{MW}$ and another in Betano (Manufahi district) with a capacity of $137 \mathrm{MW}$. These two plants are using heavy fuel oil, but in the future, they can be retrofitted to use diesel or natural gas [30]. Taking into consideration the estimated usable biomass (Table 1) and assuming a $20 \%$ efficiency for a dedicated biomass power plant, this resource could guarantee the operation of at least $400 \mathrm{MW}$ around the clock. Considering a typical biomass plant (approximately $10 \mathrm{MW}$ electrical), this biomass could be funneled to approximately 40 plants dispersed throughout the country. This suggests that all the electricity generation could be provided by existing biomass resources, with spare capacity for future development. Such distributed generation capacity is mostly adequate for the country as the distribution network is limited in extension and unreliable in operation.

Energy consumption will certainly increase with population growth and with economic development. Back in 2011, it was expected that electricity consumption would increase from $160 \mathrm{GWh}$ up to $800 \mathrm{GWh}$ by 2020 [19]. In order to support the energy consumption on generator power, the requirement to develop renewable energy becomes significant. The potential renewable 
energy projects identified by the Strategic Development Plan exceeded $450 \mathrm{MW}$ which is distributed by various technologies, as described in Figure 4 [19].

Based on the above information, the development of renewable energy, especially, in rural areas will benefit the people in remote areas. Several families in TL have benefited from the development of this renewable energy; approximately 8000 families in remote areas now have direct access to energy through the use of renewable energy resources. However, the development of more renewable energy resources is necessary to supply energy to other families and meet the expected future demand. There are still about 50,000 families who are not covered by the network distribution and do not have access to renewable energy systems [19]. In this scenario, biomass can provide a strong backbone for such development.

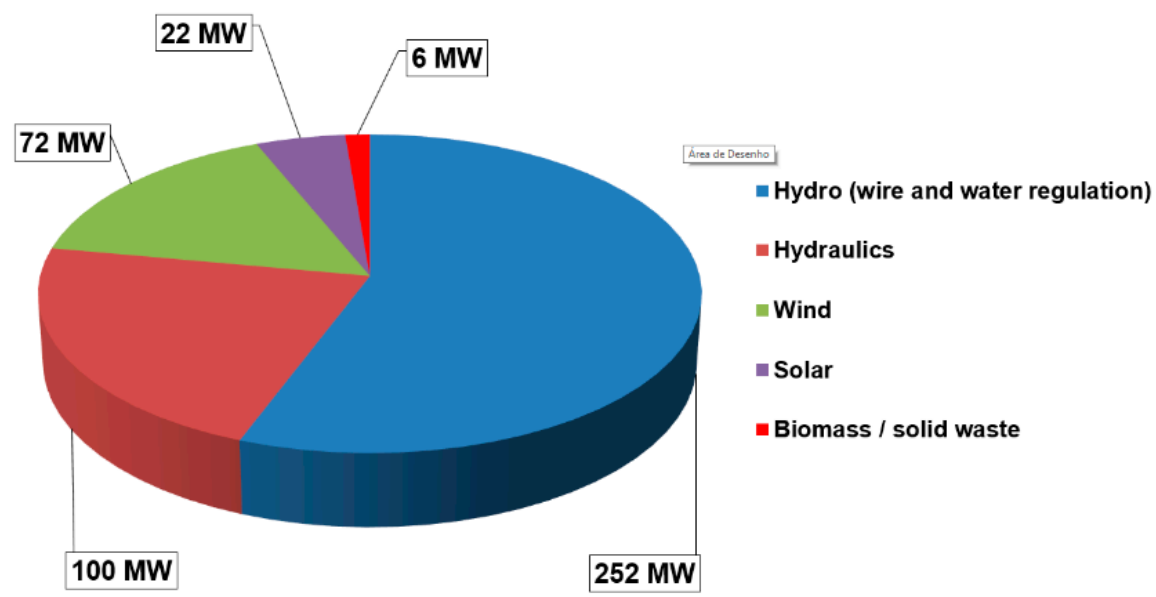

Figure 4. Potential of renewable energy projects technologies [19].

\section{Conclusions}

This paper presents an overall view of the energy scenario in TL regarding renewable resources. Specific attention is dedicated to biomass. As a tropical country, TL has a potential for developing endogenous renewable energy resources, such as wind, solar, hydropower, and bioenergy, including bioethanol, biogas, and biomass. Some initiatives to develop renewable energy have been implemented, but the absence of further development may prevent sustainable implementation in the future. If the biomass potential is properly managed, it can be developed to produce energy needs. Otherwise, this opportunity could be wasted.

The energy potential of biomass in TL, apart by vegetation or flora and animals, results also from the agricultural waste, such as waste from rice, corn, and coffee, animal, and urban solid waste. The potential of usable biomass energy in TL from forestry and agriculture is $1.68 \times 10^{6}$ toe/year, animal waste is $4.81 \times 10^{3}$ toe/year, and urban solid waste amounts to $9.55 \times 10^{3}$ toe/year.

Forestry is the largest source of biomass while agriculture waste results from rice, corn, and coffee plantations.

The data presented in this paper show that biomass could be used to generate electricity and displace costly fossil fuels either directly through dedicated biomass-powered plants or through co-firing (wood biomass blended with coal). This route has been successfully developed in the European Union [31].

Author Contributions: In this manuscript, all the authors have contributed to developing and finalizing the article: conceptualization, L.G.F. and M.E.C.F.; methodology, L.G.F.; validation, L.G.F., M.E.C.F. and J.C.F.T.; formal analysis, L.G.F.; investigation, L.G.F.; resources, M.E.C.F.; writing-original draft preparation, L.G.F.; writing-review and editing, L.G.F. and J.C.F.T.; visualization, L.G.F. and J.C.F.T.; supervision, J.C.F.T.; project administration, J.C.F.T.; funding acquisition, J.C.F.T.

Funding: This work is supported by FCT with the Reference Project UID/EEA/04436/2013, by FEDER Funds through the COMPETE 2020-Programa Operacional Competitividade e Internacionalização (POCI) with the 
Reference Project POCI-01-0145-FEDER-006941. This work was financed by FCT, under the Strategic Project UID/SEM/04077/2013; PEst2015-2020 with the Reference UID/CEC/00319/2013.

Acknowledgments: Lelis Fraga acknowledges Universidade Nacional Timor Lorosa'e for granting the leave of absence to complete his Ph.D.

Conflicts of Interest: The authors declare no conflict of interest.

\section{References}

1. Saidur, R.; Abdelaziz, E.A.; Demirbas, A.; Hossain, M.S.; Mekhilef, S. A review on biomass as a fuel for boilers. Renew. Sustain. Energy Rev. 2011, 15, 2262-2289. [CrossRef]

2. Oyedeji, O.; Fasina, O. Impact of drying-grinding sequence on loblolly pine chips preprocessing effectiveness. Ind. Crops Prod. 2017, 96, 8-15. [CrossRef]

3. Renewable Energy Policy Network for the 21st Century (REN21). Renewables 2018 Global Status Report. 2018. Available online: http://www.ren21.net/wp-content/uploads/2018/06/17-8652_GSR2018_FullReport_we b_final_.pdf (accessed on 11 April 2019).

4. International Energy Agency (IEA). Renewables Information 2018: Overview; OECD/IEA: Paris, France, 2018; pp. 1-492.

5. Ürge-Vorsatz, D.; Gomez-Echeverri, L.; Clair, A.L.S.; Jones, F.; Graham, P. Review of targets for the sustainable development goals: The science perspective. 2015. Available online: https://www.researchgate.net/publicati on/272238116_Ensure_access_to_affordable_reliable_sustainable_and_modern_energy_for_all (accessed on 11 April 2019).

6. FAO. OECD-FAO Agricultural outlook 2018-2027, Special focus: Middle East and North Africa. 2018. Available online: https:/www.oecd-ilibrary.org/docserver/agr_outlook-2018-en.pdf?expires=1555005248\&i $\mathrm{d}=\mathrm{id} \&$ accname=guest\&checksum=045BE3E9970080E767AE3736FF60DF09 (accessed on 11 April 2019).

7. Thrän, D.; Seidenberger, T.; Zeddies, J.; Offermann, R. Global biomass potentials—Resources, drivers and scenario results. Energy Sustain. Dev. 2010, 14, 200-205. [CrossRef]

8. González, J.F.; Ledesma, B.; Alkassir, A.; González, J. Study of the influence of the composition of several biomass pellets on the drying process. Biomass Bioenergy 2011, 35, 4399-4406. [CrossRef]

9. Euh, S.H.; Kafle, S.; Choi, Y.S.; Oh, J.H.; Kim, D.H. A study on the effect of tar fouled on thermal efficiency of a wood pellet boiler: A performance analysis and simulation using Computation Fluid Dynamics. Energy 2016, 103, 305-312. [CrossRef]

10. Alakoski, E.; Jämsén, M.; Agar, D.; Tampio, E.; Wihersaari, M. From wood pellets to wood chips, risks of degradation and emissions from the storage of woody biomass-A short review. Renew. Sustain. Energy Rev. 2016, 54, 376-383. [CrossRef]

11. Posom, J.; Shrestha, A.; Saechua, W.; Sirisomboon, P. Rapid non-destructive evaluation of moisture content and higher heating value of Leucaena leucocephala pellets using near infrared spectroscopy. Energy 2016, 107, 464-472. [CrossRef]

12. Fraga, L.; Teixeira, J.C.F.; Ferreira, M.E.C. Technical review on biomass resource for wood pellets in Timor-Leste. In Proceedings of the 2018 3rd International Conference, Production of Scientific Knowledge in Timor-Leste, Dili, Timor-Leste, 12-14 September 2018; pp. 1-13.

13. Wang, M.; Dunn, J.B. Comments on Avoiding Bioenergy Competition for Food Crops and Land by Searchinger and Heimlich; Argonne National Laboratory: Argonne, IL, USA, 2015; pp. 1-9. Available online: https://www.bing.com/search?q=comments+on+avoiding+bioenergy+competition+for+food+crops+an $\mathrm{d}+$ land+by+searchinger+and+heimlich\&form=EDGTCT\&qs=PF\&cvid=4476df8f29454458bb981e29bf73 6f84\&refig=58af687fb9194d97cd4e4f1939c35142\&cc=PT\&setlang=en-GB (accessed on 11 April 2019).

14. Pires, A.M. Disponibilidade de Biomassa em Timor Leste. Avaliação de potencial e de disponibilidade para aproveitamento para produção de energia eléctrica; MEGAJOULE: Oporto, Portugal, 2009; pp. 1-70. (In Portuguese)

15. Ferreira, E.d.S. Launch of the Main Results of the 2015 Census of Population and Housing; Census presentation; La'o Hamutuk: Dili, Timor-Leste, 2016; Available online: https:/www.laohamutuk.org/DVD/DGS/Cens15/ Launch_2015_census_presentationEn.pdf (accessed on 11 April 2019).

16. MacDougall, J. 13591STL-Crise da Electricidade (2-Hotu). (Expand messages by Vicente Mau Bocy); Suara Timor Lorosae: Dili, Timor-Leste, 2007. 
17. Costa, L.; Meitiniarti, V.I.; Mangimbulude, J.C. Manajemen sampah perkotaan di kota Dili, Timor Leste. BioS Maj. Ilm. Semipopuler 2012, 5, 1-7. (In Indonesian)

18. Esteves, T.C.d.J. Study of the bioenergy potential in the centre region of Portugal. Master Thesis, Univerdade Nova de Lisboa, Lisbon, Portugal, November 2010.

19. PED. Timor-Leste plano estratégico de desenvolvimento 2011-2030; Republic Democratic of Timor-Leste: Dili, Timor-Leste, 2011; pp. 1-279. (In Portuguese)

20. MF. Orçamento geral do estado 2012 planos de acção anual livro 2; Republic Democratic of Timor-Leste: Dili, Timor-Leste, 2012; pp. 1-384. (In Portuguese)

21. Geoscience Australia and Abare. Solar energy. In Australian energy resource assessment; 2010; pp. 261-284. Available online: https:/www.arena.gov.au/assets/2013/08/Chapter-10-Solar-Energy.pdf (accessed on 11 April 2019).

22. Hoeiseth, J.; Klei, K. Gariuai mini HEP: The first hydroelectric plant in a new country. In Proceedings of the 2007 International Conference on Small Hydropower, Kandy, Sri Lanka, 22-24 October 2007; pp. 1-9. Available online: http://www.ahec.org.in/links/International\%20conference\%20on\%20SHP\%20Kandy\%20Sr ilanka\%20All\%20Details/Papers/Policy,\%20Investor\%20\&\%20Operational\%20Aspects-C/C22.pdf (accessed on 11 April 2019).

23. Ferreira, S.; Monteiro, E.; Brito, P.; Vilarinho, C. Biomass resources in Portugal: Current status and prospects. Renew. Sustain. Energy Rev. 2017, 78, 1221-1235. [CrossRef]

24. Forest plantation yields in the tropical and subtropical zone. Available online: http://www.fao.org/3/X8423E /X8423E08.htm (accessed on 22 March 2019).

25. Sebastian, R.M.; Kumar, D.; Alappat, B.J. A technique to quantify incinerability of municipal solid waste. Resour. Conserv. Recycl. 2019, 140, 286-296. [CrossRef]

26. Statistika, D.N. ATLAS—Sensus ba populasaun ho uma-kain 2004; Republic Democratic of Timor-Leste: Dili, Timor-Leste, 2006; pp. 1-92.

27. Jemaga, G. Pentingnya pengelolaan sampah di Kota Kupang. 2011. Available online: http://administrasikebija kankesehatan.blogspot.com/2011/03/pentingnya-pengelolaan-sampah-di-kota.html (accessed on 11 April 2019).

28. Press-Release. Parseria foun entre MOP no PNUD atu kombate deflorestasaun, salva vida no kria kampu serbisu; United Nations Development Programme (UNDP): Dili, Timor-Leste, 2014; (In Tétum).

29. Hamutuk, L. Report Title; Annual Report; La'o Hamutuk: Dili, Timor-Leste, 2011; pp. 1-35.

30. Hamutuk, L. Power plant and national electrical grid 2011-17. Available online: https://www.laohamutuk.o rg/Oil/Power/2011/11PowerPlant2011.htm (accessed on March 11, 2019).

31. Hoefnagels, R.; Junginger, M.; Faaij, A. The economic potential of wood pellet production from alternative, low-value wood sources in the southeast of the U.S. Biomass Bioenergy 2014, 71, 443-454. [CrossRef] 